\title{
Post-War Korean Conservatism, Japanese Statism, and the Legacy of President Park Chung-hee in South Korea
}

\author{
Minji Jeong and Youseop Shin
}

\begin{abstract}
Former President Park Chung-hee ruled South Korea from 1961 to 1979. During this period, his ideas were deeply engraved in Korean society. Even in the present day, his conservative ideas are a source of continuing controversy. To understand conservative ideas and ideological disputes between conservatism and progressivism in Korea, it is important to objectively understand Park's ideas. To this end, we analyze his ideas in relation to Japanese statism. We do not intend to resolve the long-standing controversies over whether Park was pro-Japan during the colonial period or whether his ideas and policies benefited Korea. Nor do we intend to evaluate his ideas in a wholly negative light by arguing that they were influenced by Japanese statism. Various legitimate stances can be taken toward statism, in general, and Park's ideas, in particular, and it is not our purpose to evaluate these stances. In this article, we show that there is a resemblance between conservative characteristics of Japanese statism-a mixture of militarism, elitism, and physiocracy-and Park's ideas and his policies.
\end{abstract}

Key Words: Korean conservatism, Japanese statism, European fascism, progressivism, Park Chung-hee

*Minji Jeong(jeong23@uchicago.edu) received M.A. in Social Sciences from the University of Chicago and M.A. in Political Science from Yonsei University. She served as a Political and Economic Analyst at the Korean Embassy in Rwanda and a Researcher at the Yonsei Institute for North Korean Studies.

** Youseop Shin(sys64@yonsei.ac.kr), corresponding author. Professor Shin is in the Department of Political Science \& International Studies at Yonsei University in Seoul. 
$\mathrm{M}$ any South Koreans today tend to be intolerant toward progressive ideas, ${ }^{1}$ regarding them as impure, leftist ideologies held by those with favorable attitudes toward North Korea (Kwon 2000; Sohn 1983; Tikhonov 2000). As a result, progressive ideas have not been able to gain a strong foothold in South Korea. This phenomenon can be partly attributed to the legacy of the ideology developed by former President Park Chung-hee in the first half of the twentieth century, which indoctrinated Koreans with conservative ideas that lasted well beyond his nearly twenty-year tenure in office.

Most studies of Park Chung-hee have discussed Park's achievements in office, focusing on contemporary factors that influenced his choices, such as political turmoil, economic adversity, and threats to national security (Cho 2007; Kim 1995; Kim 2004; Kim and Vogel 2011; Lee, 2005; Rhyu 1996), and his negative impact on Korean politics, such as his suppression of progressive movements and creation of a coercive political culture that contributed to postponed democratization (Im 2012; Kim 2011; Kim 2012). Some studies have focused on evaluating his experiences during the Japanese colonial period (Chun 2006; Chung 1992; Han 2005; Sin 2002). Studies of Park's ideas have tended to focus on their authoritarian and conservative characteristics (see, for example, Kang and Ha 2012; Park 2006).

There has been insufficient discussion regarding the non-political characteristics of Park's ideas as revealed in his strongly anti-communist economic and social policies. Different from studies that have focused on the authoritarian characteristics of his administration or on the question of his legitimacy, this article analyzes Park's ideas in the context of Japanese statism. In this article, we argue that there are common themes shared by Japanese statism and Park's conservative ideas reflected in his policies, as the conservative characteristics of Japanese statism can be seen in the methods by which Park realized his ideas while in office. This article does not intend to resolve the longstanding controversies over whether Park was pro-Japan during the colonial period or whether his ideas and policies benefited Korea. Nor does it intend to evaluate his economic policies in a negative light by connecting them with

\footnotetext{
${ }^{1}$ Progressivism in general emphasizes the government's role in solving social problems, such as poverty, economic inequality, social injustice, and monopolistic corporations (Walter 2010; Milkis and Mileur 1999). Progressivism in South Korea shares these characteristics, but it also has special characteristics that stemmed from South Korea's unique modern experiences, such as the Korean War and centrally-controlled economic development under authoritarian regimes (Kim 1965; Kang 2005). For example, progressives in South Korea strongly oppose anti-communist policies, emphasizing individual freedom and human rights, while conservatism emphasizes authority and social order.
} 
Japanese statism. A variety of legitimate stances can be taken toward Japanese statism and Park's ideas; however, it is not the purpose of this article to evaluate those stances.

In this article, we pay closer attention to the common themes shared between Park's ideas and statism as a possibly politically neutral explanation of Park's ideas. We think that such an approach can help us view Park's policies from a more politically neutral standpoint, considering the possibility that Park's policies might not simply reflect the authoritarian nature of his administration and that they might not have been pursued simply to make up for his administration's lack of legitimacy. Furthermore, the authoritarian, anti-communist nature of the Park administration might not be a reaction to North Korea. This approach may also help us determine which of Park's ideas we include when we try to define Korean conservatism. The next section briefly summarizes what is Japanese statism, highlighting aspects that must be known in order to understand Park's ideas.

\section{JAPANESE STATISM}

Japanese statism (Kokka shugi, 國家主義) is a mixture of such conservative ideas as militarism, elitism, state capitalism, and anti-communism, and it has developed in three stages. ${ }^{2}$ First, an immature movement was stirred as people resisted the new left-wing movement-also known as 'Bolshevization'-during the preparatory period (1919-1931) lasting from the end of the First World War until Japan's invasion of the northern part of China, known as Manchuria.

Second, right-wing philosophers such as Kita Ikki, Okawa Shumei, and Michikawa Kametaro organized the conservative group called the Society of Those Who Yet Remain (Yuzonsha, 猶存社) and led a right-wing movement during the period of maturity (1931-1936). The Yuzonsha started as a small group but gradually absorbed more and more right-wing elements. According to An Outline Plan for the Reorganization of Japan, which laid out the group's philosophical platform, Yuzonsha advanced the construction of a revolutionized Japan, the coordination of reform movements, and emancipation of the Asian people (Maruyama 1963). This group influenced several important events, such as the May 15 Incident and the February 26 Incident. On May 15, 1932, young officers of the Imperial Japanese Navy assassinated the Prime Minister. After this incident, military authorities gained power and weakened party politics

\footnotetext{
${ }^{2}$ For a detailed explanation of the three stages, see Maruyama (1963, 26-34).
} 
(Matsumoto 2010). On February 26, 1936, young officers of the Imperial Way Faction (Kodoha, 皇道派), one of the military cliques that espoused an absolutist emperor system with unconditional power and national innovation that centered on the emperor, assassinated several leading politicians, including the finance minister and two former prime ministers (Crowley 1962; Lee 2008). Their purpose was to reorganize the Japanese political system in such a way as to give more power to Emperor Hirohito. ${ }^{3}$

The last stage of Japanese statism, the consummation period (1936-1945), began with the purge of the Japanese military following the February 26 Incident and ended with the conclusion of the Second World War. After the February 26 Incident, the military, together with bureaucrats and capitalists, created a ruling structure to impose statism from above under the slogan of strengthening state control.

Japanese statism originated from a political ideology that in Europe is generally referred to as fascism, and it shared typical elements of European fascism. For this reason, some studies use the term Japanese fascism instead of Japanese statism (Gordon 2002; Maruyama 1963).

European fascism developed as a reaction to ideas such as rationalism, liberalism, capitalism, and communism, all of which had dominated political thought since the French Revolution. ${ }^{4}$ European fascism either underestimated or outright rejected the values of rationality and individual freedom. It asserted that individual identity could be expressed only through the whole and that individuals must be entirely absorbed into the community.

European fascists criticized financial capital but showed a permissive attitude toward industrial capital and private ownership on the grounds that economic development contributed to the prosperity of the nation. European fascists allowed for the private means of production under the condition that the state had considerable control over the allocation of credit and investment. For example, Benito Mussolini, the leader of the National Fascist Party in Italy, claimed that Italians should slide into state capitalism for the bureaucratization of the national economy. ${ }^{5}$

European fascism was strongly opposed to communism. The area in which European fascism contrasted most sharply with communism was fascism's

${ }^{3}$ The February 26 Incident was not successful. The leaders either committed suicide or were executed. After this incident, generals associated with the Imperial Way Faction were disgraced and lost their power in the Imperial Army. See Crowley 1962; Holcombe 2011; and Matsumoto 2010. (1997).

${ }^{4}$ For a discussion of European fascism, see Heywood (2007); Griffin (1995); and Neocleous

${ }^{5}$ See "Address to the National Corporative Council" (November 14, 1933) in Mussolini 1935. 
understanding of social classes. Given that the top priority of fascism was national restoration, fascists did not believe that proletariats and capitalists should form classes with distinct interests that were in conflict. To European fascists, the state was far more important than social class. In addition, in forming a hierarchy among races, thereby making race a concept superordinate to class, fascism eliminated the feasibility of international class struggle. In addition, European fascists thought that it was impossible to unite with proletariats of other countries.

Japanese statism shared these elements of European fascism. Like European fascism, the top priority of Japanese statism was national restoration. Consequently, it fostered a strongly hostile attitude toward communists, whose goal was a stateless society and who saw the state only as a necessary evil until a classless society could be created. This communist view of the role of the state did not align with Japanese statism, whose goal was to restore the Japanese political system in such a way as to give more power to Emperor Hirohito (Crowley 1962; Lee 2008; Matsumoto 2010). ${ }^{6}$

Like European fascism, Japanese statism downplayed the importance of individual liberty (Maruyama 1963; Yanga 1940). For example, Kita Ikki, an ideological leader of the February 26 Incident and a spiritual guide to the Imperial Way Faction, saw the state as a larger version of the self and individuals as molecules of a larger organ, the state (Matsumoto 2010). He believed that individuals should merge with the state, which was expected to persist for thousands of years, to make their lives more meaningful. Furthermore, he asserted that the success of the state ultimately was a product of the individuals who live there.

Like European fascism, Japanese statism pursued deep and extensive industrialization on the condition that industries were placed under state control, as observed in a series of five-year centralized economic plans that focused on capital investment in selected industries (Gordon 2002). For example, Tachibana Kosaburo, who provided intellectual justification for fascistic actions such as the May 15 Incident and the February 26 Incident, argued that a largescale machine-building sector was allowable if it was controlled well (Maruyama 1963, 43).

\footnotetext{
${ }^{6}$ Wartime extremism has occurred in many countries waging war, so we may not always have a need to attribute it to a coherent set of ideas. Trying to understanding this period of Japanese history only through the rubric of ultra-nationalism may conceal or conflate many important issues that potentially were structural in character and not necessarily ideological. This article does not focus on the structural issues informing Japanese statism during the Second World War, as they were unrelated to Park's ideas being discussed here.
} 
Japanese statism, however, differed from European fascism in several aspects (Maruyama 1963). First, Japanese statism was a top-down political ideology that eschewed efforts to gather support from the masses, while European fascism was a bottom-up political ideology where success was based on mass support (Chung 2007). In Italy and Germany, fascism began as a civil movement that eventually seized political power through mass mobilization, whereas in Japan, top government officials and military officers were at the center of the creation of the new political system, as observed in the May 15 Incident and the February 16 Incident. Japanese statism emphasized the noble duty of men of high purpose (shishi, 志士) (Koschmann 1987). For example, Tachibana Kosaburo argued that only a small number of people, especially military officers, were capable of leading the revolution (Maruyama 1963).

Another difference was that European fascism focused on, and controlled, industrial workers, whereas Japanese statism focused on farmers and permitted autonomy for rural agricultural societies. For example, while the National Socialist German Workers' Party (Nazi Party) claimed to stand for workers, the Imperial Japanese government valued peasants and merchants more than factory workers. The Japanese government even ignored the exploitation of workers, as it dissolved all labor unions in 1940 (Maruyama 1963).

This physiocratic characteristic of Japanese statism was similar to European physiocracy. ${ }^{7}$ However, the former was not modeled consciously on the latter. It was based on Japan's traditional belief that agriculture formed the basis of the nation's economy and that the state was an extension of the agrarian family system (Ibid.).

\section{PARK'S EXPERIENCES DURING THE JAPANESE COLONIAL PERIOD}

Park lived under Japanese colonial rule for 28 years, and during that time he was regularly exposed to features of Japanese statism. Therefore, we need to pay attention to the possibility that Park might have assimilated statist ideas into his thinking and that we may better understand his behavior in the context of Japanese statism. $^{8}$

\footnotetext{
${ }^{7}$ Physiocracy is an economic theory that the wealth of nations is derived from the value of agriculture or land development. French economists developed the theory in the 18th century (see Steiner 2003).

${ }^{8}$ Park's exposure to Japanese statism during the colonial period does not necessarily provide sufficient evidence that he affiliated himself with Japanese statism. We examined Park's experienc-
} 
Park's life during Japan's colonial rule can be divided into two periods that were marked by distinct personal experiences: his life from the time he entered Daegu Teacher's College until he took up a teaching position at Mun-gyeong Common School (1932-1940), and his life at the Japanese Manchurian Military Academy and serving in the Kwantung Army (1940-1945).

During the colonial period, education was primarily a tool for molding Koreans into Japanese citizens; therefore, heavy emphasis was placed on moral and political instruction. For example, according to the Ordinance on Chosun Education, students were expected to cultivate moral virtue, which in effect meant blind allegiance to the political system. ${ }^{9}$ By the time Park entered Daegu Teacher's College, Japan had begun actively imposing its 'Japanization' policies, a coercive program of ethnic assimilation: students were unable to express defiance towards the institution, and educators evaluated the personal qualities of students, such as ideologies, outlooks, and hobbies, in addition to academic performance (Gordon 2002). Japanization refers to a comprehensive attempt to assimilate Koreans into the Japanese empire, imposing not only Japanese language but also Japanese culture. For instance, the Japanese government banned the use of Korean in schools, replaced Korean names with Japanese names, and prevented the publication of Korean newspapers except Daehan Maeil Sinbo (Daehan Daily newspaper), which was published by British journalist E. T. Bethell. ${ }^{10}$

Daegu Teacher's College was established as an institution that fostered instructors who had appropriate understanding of Japan's militaristic system and who could educate students to be loyal to the emperor. The college was similar to a military academy: all students lived in a dormitory under surveillance and received military-style education; military drills and gymnastics were emphasized among many other courses; and fourth-year students were sent for military service during school vacations (Cho 1998; Chung, 1992; Lee 2002).

Japan had limit success in Japanizing students at the college. ${ }^{11}$ Throughout

es during this period to show that he was regularly exposed to Japanese statism in action, and that these ideas appeared to have something in common with Park's during his tenure as South Korea's leader.

${ }^{9}$ The Ordinance prescribed the general direction of education in 'Chosun' Korea, including matters related to discrimination and imperial rule. In addition, the Ordinance regulated details related to subjects, weekly teaching hours, and curriculum content. See Kim 2009.

${ }^{10}$ For a detailed explanation of Japan's assimilation policies, see Caprio 2009.

${ }^{11}$ For example, many Korean students, including Park, subscribed to Korean newspapers and did not wear Geta (Japanese traditional sandals) in the dormitory. See Cho 1998 and Chung 1992. 
students' five years of education at the Teacher's College, statism likely becameconsciously or unconsciously-ingrained in their thinking. For example, immediately after Park graduated, several students in the College voluntarily formed a secret organization characterized by themes of elitism and militarism (Lee 2002). Park, too, was likely tinged with statist beliefs. He did exceptionally well in military drills and history; the latter of which was taught by a teacher who supported the Imperial Way Faction (Lee 2002). Park himself, like his Korean teachers at the College, later tried to arouse his students' nationalist sentiments at Mun-gyeong Common School (Chung 1992).

In 1940, Park resigned from Mun-gyeong Common School and joined the Japanese Manchurian Military Academy. He seemed to decide to try to succeed within the Japanese empire system, rather than to actively fight against it. After more than thirty years of Japanese colonial rule, the number of Koreans who were trying to elevate their social position within the empire system was increasing at that time. ${ }^{12}$ Park then stayed in Manchuria until Japan's defeat in 1945.

Park was constantly exposed to Japanese statism, such as militarism, elitism, and anti-communism, through his experiences in the Japanese Manchurian Army. The Manchurian Military Academy was established for two main purposes (Sin 2002). The first was to stabilize Manchuria by suppressing anti-Japanese armed groups. The second was to build a stable front against the Soviet Union. The Manchurian Military Academy was not a regular institution with a fouryear curriculum. It was a two-year preparatory institution. The curriculum of the Academy, however, was similar to that of the Imperial Japanese Army Academy in Japan. Courses included Japanese history and world history. In these classes, students received spiritual education that emphasized the Japanese way of the warrior and the Japanese spirit (Ibid.). In addition, Kanno Hiroshi, who had participated in the February 26 Incident, served as one of Park's instructors in the Manchurian Military Academy (Cho 1998; Chun 2006). It is likely that Hiroshi's ideological positions influenced Park, as Park expressed interest in the February 26 Incident (Chun 2006), and, in 1961, actually carried out a similar coup d'état to gain political power. After the success of the 1961 coup d'état, Park exerted strong leadership as the president under the slogan of remaking South Korea, similar to how the rebels in the February 26 Incident had attempted to reorganize the Japanese political system in such a way as to give more power to Emperor Hirohito (Kim and Vogel 2011).

\footnotetext{
${ }^{12}$ For example, every year about 10,00o students applied for the Manchurian Military Academy (see Sin 2002).
} 
At that time, the Soviet Union and Japan were engaged in a border conflict involving the line between Manchuria and Mongolia. The Nomonhan Incident, one of the signature events of the conflict, broke out one year before Park entered the Manchurian Military Academy. ${ }^{13}$ Strong feelings of antipathy toward the Soviet Union existed among Japanese soldiers when Park arrived in Manchuria. Park's experiences in Manchuria likely especially influenced the anti-communist views that he espoused during his presidency, as he took a strong stance against the Soviet Union, which he perceived as a threat to the security of Korea (Park 2005).

After Park graduated from the Manchurian Military Academy, he got into the Imperial Japanese Army Academy, the regular Military Academy in Tokyo, which was abolished along with the Imperial Japanese Army at the end of 1945 . Its curriculum was similar to that of the Manchurian Military Academy because the latter originally modeled its curriculum on that of the former (Sin 2002). At the Imperial Japanese Army Academy, Park was not 'Japanized,' according to the recollection of one of Park's classmates (Chung 1992). However, Park did graduate from the Academy near the top of his class. After graduation, he was assigned as a probation officer to the 636 unit of the Kwantung Army, located in the border area between the Soviet Union and Manchuria.

\section{PARK'S EXPERIENCES AFTER THE JAPANESE COLONIAL PERIOD}

Shortly after July 1945, when Park was promoted to a first lieutenant, Korea gained its independence. Immediately after the collapse of the Japanese Empire, soldiers and officers who had served in the Manchurian Army or the Japanese Army converged on Beijing to join the Korean Liberation Army (Park 2004). Park became commander of a company of soldiers in the third detachment of the Korean Liberation Army.

Park's experiences in Beijing likely strengthened his anti-communism. At that time, the civil war between Chinese communists led by Mao Zedong's Communist Party of China (CPC) and Chinese nationalists led by Chiang Kaishek's Kuomintang Party was in its final phase (Westad 2003). During the

\footnotetext{
${ }^{13}$ The Nomonhan Incident refers to a series of border disputes in 1939 between Manchuria, a puppet state of the Japanese Empire, and the Mongolian People's Republic, a puppet state of the Soviet Union. The Soviet Union set the border on the east side of Halha River near Nomonhan village. The Kwantung Army and Manchuria lost the battle and accepted the border as defined by the Soviet Union and Mongolia. For details, see Cox 1985.
} 
Chinese civil war, both the Soviet Union and North Korea contributed to the victory of the CPC in Manchuria (see Chen 1994; Sheng 1997). The Soviet Red Army delayed pulling out of Manchuria, thereby allowing CPC forces to move into Manchuria before Chiang Kai-shek's troops gained control of the region. North Korea provided weapons, manpower, and a safe refuge to the Chinese People's Liberation Army. Park observed the defeat of the Kuomintang, which early on had been expected to win the civil war, and its retreat from Mainland China to the island of Taiwan.

Additionally, an antagonistic relationship between left-wing and right-wing elements-an enduring problem in Korea-had already formed in the Korean Liberation Army, with left-wing soldiers frequently engaging in all-night debates over ideology. Park had a poor relationship with these left-wing soldiers, who frequently disobeyed his orders not to go to Communist Party meetings during training sessions (Chun 2006; Cho 1998).

After Park returned to Korea, he enrolled in a three-month course at the South Chosun Defense Academy, which was formerly the Military Language School. Administrators in the U.S. military originally planned to fill the Military Language School with officers from the Korean Liberation Army, the Imperial Japanese Army, and the Manchurian Army. However, the Korean Liberation Army rejected this plan because they did not want to cooperate with those whom they viewed pro-Japanese betrayers. Consequently, in both the South Chosun Defense Academy and the Military Language School, most teachers were from either the Imperial Japanese Army or the Manchurian Army (Jo 1989). The ideas of these teachers likely had been influenced by Japanese statism, which means that Park likely was under the influence of Japanese statism during his time at the South Chosun Defense Academy.

Subsequently, Park became a second lieutenant in the South Chosun National Defense Force. In 1948, Park was expelled from the army during a military purge sparked by the Yeosu-Suncheon Rebellion, a communist-led insurrection among Korean soldiers in Yeosu, Suncheon, and surrounding towns. It was alleged that, under the influence of his elder brother Park Sang-hee, he joined the South Korean Workers Party and participated in a communist cell (Han 2011). In the purge that followed, many who were accused of participating in the communist cell were sentenced to death. Park, however, proved that he was not a communist by revealing core information about the South Korean Workers Party. ${ }^{14}$ Several

\footnotetext{
${ }^{14}$ Despite Park's anti-communist ideology, his participation in a left-wing coup upon his immediate return to Korea suggests that whatever doubts he might have had, he was still open to leftist ideas. Given the contradictory nature of the evidence, this is a debate that cannot be definitively resolved.
} 
prominent military officers, including Baek Sun-yeop and Kim Chang-ryoung, helped him dispel the allegations concerning his involvement in the cell. In addition, James H. Hausman, a U.S. advisor, suggested to President Syngman Rhee that amnesty be given to Park (Chung 1992). This incident marked the only time when Park was said to have shown a favorable attitude toward communism. The onset of the Korean War provided Park with an opportunity to prove his ideological fitness and finally dispel any remaining suspicions about his support for communism. From that point on, Park's ideas and his policies were strongly anti-communist.

The political situation under President Syngman Rhee (1948 to 1960) was a favorable one for Park, and his ideas developed as a result of his experiences during the Japanese colonial period. President Rhee and his administration opposed purging those who had actively collaborated with Japan during the colonial period. Instead, Rhee hired many of them as government officials and military officers to combat North Korea and communists in South Korea ${ }^{15}$ In addition, Rhee dissolved the Special Investigation Committee on Collaborationist Activities, which was created to purge those who had collaborated with Japan during the colonial period. Consequently, government officials and military officers who had served in the Japanese empire were not criticized or punished for what they had done during the colonial period. This situation likely contributed to an ideological continuation of statist conservatism among government officials and military officers, including Park.

\section{JAPANESE STATISM AND PARK'S IDEAS}

The commonalities between Park's ideas and Japanese statism can be found in his political choices, including his obtaining political power through a coup d'état; his elite-driven reforms; his self-sustaining rural development policies based on his belief that agriculture formed the basis of the nation's economic and social life; his developmental dictatorship; his oppressive labor policies; and his strong anti-communist policies.

Just as Kita Ikki had asserted that Japan should re-establish a powerful emperor system by reorganizing its political system by means of a military coup (Matsumoto 2010; Szpilman 2002; Wilson 1966), Park obtained political power through a coup d'état. Park's military coup on May 16, 1961 put an end to

\footnotetext{
${ }^{15}$ About 30 percent of the 96 cabinet members in the Rhee administration were said to have collaborated with Japan during the colonial period (Lim 1991).
} 
the Second Republic of Korea. As the leader of the coup d'état, he argued that creating a strong government would allow him to solve social problems, such as anarchy, as well as address security threats from North Korea and, more broadly, from communism (Brazinsky 2007; Hong 2012; Han 2011; Ma 2002).

In 1972, Park dissolved the National Assembly and suspended the constitution. Then, a new constitution, which created the Yushin (Revitalizing Reform, 維新) system, was approved in a referendum. Highly centralized government control was a core feature of Park's Yushin system (Yi 2006; Ma 2003). The word Yushin was borrowed from the 1868 Meiji Ishin (Meiji Restoration, 明治維新) of Imperial Japan. ${ }^{16}$ As the main purpose of the Meiji Ishin was to restore imperial rule to Japan, the purpose of the Yushin was to strengthen the political power of chief executive. Under the Yushin Constitution, for example, the president was allowed to be re-elected for an unlimited number of terms. The president had the authority to dissolve the National Assembly, while the National Assembly did not have the right to impeach the president. The president had the right to appoint one-third of the legislators.

Kita believed that the individual should ultimately 'merge' with the state, which represented the larger self (Matsumoto 2010), Park, after he gained political power, emphasized commitment to the state over individual autonomy, asserting, "[W]e should abandon the self and be committed to the larger self" (Hwang 2009 ). Tachibana Kosaburo, one of the leaders of the May 15 Incident, argued that only a small group composed primarily of qualified military officers could lead such a revolution (Maruyama 1963). Park, during his presidency, pursued reforms that can only be characterized as a revolution from above (Kim 2012). In his writings, for example, Park emphasized the importance of the role of leaders:

As people do not always have good and sensible wishes, their leaders should be able to teach them, with kindness, where they have erred in their thinking and actively steer them away from bad decisions. Therefore, leaders should have the ability to perceive what is wrong with society and what will cause harm to it (Park 2005, 910).

Under the Yushin system, he vigorously and unilaterally implemented policies without giving much thought to whether they had public support, which was and continues to be a major source of criticism even by those who acknowledged his contributions to the economic development of South Korea. Park's policies

\footnotetext{
${ }^{16}$ For the Meiji Restoration, see Akamatsu 1972 and Beasley 1972.
} 
mainly reflected his own opinions and those of a small number of advisors. ${ }^{17}$ In his five-year plans for economic development, for example, one institution in particular, the Economic Planning Board, exerted unrivaled power in designing Korean economic policies (Kim 2011). This mirrors the military and bureaucracy of Japan, which had imposed five-year plans that relied on a small number of bureaucrats to regulate industries (Gordon 2002).

The idea that industrial development was productive goal of the state, if well controlled by the government-another central tenet of Japanese statism-was also echoed in a series of five-year plans for economic development that Park initiated in 1962. These plans were subject to highly centralized government control, similar to the Japanese industrial development plans of the 1930 s and 1940s. When Park began his series of five-year economic development plans, he stated, "While the economic system would respect the freedom and creativity of private companies, regarding key industries, the government will actively intervene in their decisions" (Park 2005, 524). The thinking behind Park's centrally controlled economic development plans was similar to that of Japanese bureaucrats during the Meiji Restoration. Both believed that uncontrolled profitseeking likely would harm the nation. For example, in one of his writings, Park asserted:

Large companies are crucial for economic development and the improvement of the quality of life. ... If they influence state policy through economic power, it will go against democratic principles. ... Thus, appropriate state control and supervision of large companies and their economic power are pivotal elements of liberal economic policies (Park 2005, 468-469).

The physiocracy of Japanese statism was also reflected in Park's policies. Japanese statism emphasized agriculture-first principles (Maruyama 1963), and so Park initiated the New Community Movement (Saemaeul Undong) in 1970. A major goal of the movement was to decrease the wealth gap between urban and rural areas. He believed that increasing income for farmers was crucial for development, as he stated in a public speech:

\footnotetext{
${ }^{17}$ These advisors likely shared statist conservative ideas with Park. For example, they were economic nationalists who invested heavily in the heavy and chemical industries, similar to what economic bureaucrats in Japan had done (see Cumings 1987 and Haggard 1990). In addition, several of these advisors were educated at the Manchurian Military Academy and served in the Manchurian Army. Examples are Lee Hanlim, secretary of construction, Jung Ilkwon, prime minister, and Kim Ilwhan, secretary of transportation and secretary of the interior. See Park 2002 and Sin 2002.
} 
More than sixty percent of Koreans are farmers. Rural areas can become a huge market that will contribute to industrial development. Thus, we cannot overemphasize the importance of increasing rural house-hold income (Park 2005, 470-471).

The New Community Movement emphasized the three principles of diligence, self-help, and collaboration, and it encouraged rural residents to work hard in accordance with these principles. The central government actively assisted this movement by, for example, building rural infrastructure.

As explained earlier, Japanese statism valued peasants and merchantsin contrast to European fascism, which showed greater support for workersand commonly exploited workers, such as when, in 1940, the Japanese cabinet outlawed labor unions (Gordon 2002; Maruyama 1963). Similarly, while Park was initiating the New Community Movement to improve the quality of life for farmers, he also was systemizing state control of factory workers. The Yushin system strongly suppressed labor movements under the pretext of safeguarding national security against the threats posed by North Korea and the communists. Under the Yushin system, the Special Measures for Safeguarding National Security and the National Security Act were passed. These laws did not specifically target labor unions, but under these laws, labor movements were suppressed along with other social movements (Shin 2008). Park emphasized the importance of government control of labor movements, arguing:

Labor organizations have existed in name only, and have been used politically for the benefit of the ruling class rather than of workers. ... The state should be actively involved in guiding labor movements in a more appropriate direction (Park 2005, 475).

Park's strong anti-communist views were nurtured through his experiences in the 1930 and 1940s. Anti-communism was an important factor that led him to choose excessively authoritarian methods for assuming power through a coup d'état and for ruling the country through the Yushin system. For example, Park insisted that he had to mount a coup d'état because the Chang Myon administration had allowed communism to spread in South Korea (Ibid.). In May 1961, when a group of students organized a protest in front of Panmunjomthe border town between North and South Korea-demanding to be allowed a meeting with North Korean students, Park criticized the students for being immature and easily misled by communist demagoguery. For him, this kind of social confusion was sufficiently threatening to legitimize the military coup d'état. 
Park even perceived economic development, the top priority of his regime, as a process not just of transforming an underdeveloped country into an industrial powerhouse, but also of forming a modern, anti-communist state (Shin 2006).

\section{CONCLUSION}

Studies of Park Chung-hee have neglected to examine with objectivity his ideas as revealed in his strong anti-communist, economic, and social policies. Studies of Park have tended to focus on the authoritarian characteristics of his administration or on the question of his legitimacy. Different from these studies, this article discussed the possibility that we may not satisfactorily explain the ideas reflected in Park's policies only in terms of the authoritarian nature of his administration and his administration's lack of legitimacy. Furthermore, the authoritarian, anti-communist nature of the Park administration might not have been a simple reaction to North Korea, nor was it necessarily derived from his strategies to use North Korean threats to maintain and expand his political power.

We analyzed Park's actions, beliefs, and policies in relation to Japanese statism, to which he was constantly exposed throughout his experiences during and immediately after the Japanese colonial period. We showed the commonalities between Park's ideas reflected in his economic and social policies and Japanese statism. Statism gives priority to the command of the ruler over the constitution; similarly, during the Park administration, the will of the ruler at times took precedence over the constitution, especially in matters that concerned the security and prosperity of South Korea.

Park ruled South Korea for a period of almost twenty years from 1961 to 1979 , during which time his ideas became deeply engrained in Korean society and politics, for better or for worse. Many characteristics of conservative ideas in South Korea can be attributed at least partly to Park. Even in the present day, his conservative ideas are a source of continuing controversy. For example, in 2012, his daughter, Park Geun-hye, defeated the presidential candidate of the liberal Democratic United Party, who had been an activist jailed in the 1970 s for opposing Park Chung-hee. In the 2017 presidential election that was held in the aftermath of the impeachment of Park Geun-hye following a corruption scandal, that candidate Park had defeated in 2012 was elected. Efforts to form a better understanding of Park Chung-hee's ideas during his presidency from a more objective standpoint need to draw greater scholarly attention in order to understand post-war conservatism in Korea and the ongoing ideological disputes 
between conservatism and liberalism.

\section{REFERENCES}

Akamatsu, Paul. 1972. Meiji 1868: Revolution and Counter-Revolution in Japan. New York: Harper \& Row.

Beasley, William G. 1972. The Meiji Restoration. Stanford: Stanford University Press.

Brazinsky, Gregg. 2007. Nation Building in South Korea: Koreans, Americans, and the Making of a Democracy. Chapel Hill, NC: University of North Carolina Press.

Caprio, Mark. 2009. Japanese Assimilation Policies in Colonial Korea, 19101945. Seattle: University of Washington Press.

Chen, Jian. 1994. China's Road to the Korean War: The Making of the SinoAmerican Confrontation. New York: Columbia University Press.

Cho, Chul-Ho. 2007. "President Park Chung Hee's National Defense Policy of Self-Reliance and the Development of Nuclear Weapons." Critical Review of History 80, 356-373.

Cho, Gabje. 1998. Spit on My Grave, Vol. 2. Seoul: Chosun Ilbosa.

Chun, Inkwon. 2006. A Biographical Study of Park Chung-Hee's Political Thoughts and Actions. Seoul: Ehaksa.

Chung, Chang-Suk. 2007. "A Study of Japanese Military Fascism.” Journal of Japanese Culture 34, 653-674.

Chung, Jae-kyoung. 1992. Great Man, Park Chung Hee. Seoul: Jipmoondang.

Cox, Alvin D. 1985. Nomonhan: Japan Against Russia, 1939. Stanford: Stanford University Press.

Crowley, James B. 1962. "Japanese Army Factionalism in the Early 1930's." Journal of Asian Studies 21, 309-326.

Cumings, Bruce. 1987. "The Origins and Development of the Northeast Asian Political Economy.” In F. C. Deyo ed., The Political Economy of the New Asian Industrialism. Ithaca: Cornell University Press, 75-76.

Gordon, Andrew. 2002. A Modern History of Japan: From Tokugawa to the Present. New York: Oxford University Press.

Griffin, Roger. 1995. Fascism. New York: Oxford University Press.

Haggard, Stephan. 1990. Pathways from the Periphery. Ithaca: Cornell University Press.

Han, Suk-Jung. 2005. "Those Who Imitated the Colonizers: The Legacy of the Disciplining State from Manchukuo to South Korea." In Mariko Asano 
Tamanoi ed., Crossed Histories: Manchuria in the Age of Empire. Honolulu: University of Hawaii Press, 165-183.

Han, Yong-sup. 2011. “The May Sixteenth Military Coup.” In Byung-Kook Kim and Ezra F. Vogel eds., The Park Chung Hee Era: The Transformation of South Korea. Cambridge: Harvard University Press, 35-57.

Heywood, Andrew. 2007. Political Ideologies-An Introduction, 4th ed. New York: Palgrave Macmillan.

Holcombe, Charles. 2011. A History of East Asia: From the Origins of Civilization to the Twenty-First Century. London: Cambridge University Press.

Hong, Seuk-Ryule. 2012. "Military Purification Movement after the April Revolution and 5.16 Coup in South Korea." Journal of Korean History 158, 197-230.

Hwang, Byoung Joo. 2009. "Park Chung Hee and the Desire for Success in Modern Korea." Critical Review of History 89, 257-283

Im, Hyuk-Back. 2012. "Political Analysis of Park Chung Hee: Leadership, Modernization, Yushin and Park's Demise.” Peace Studies (Fall), 51-84

Jo, Hyunwoo. 1989. "Park Chung Hee, from Commissioned Officer in the Japanese Army to President." Word Monthly 42, 136-139.

Kang, Jung-In and Sang-Bok Ha. 2012. "Park Jung-Hee's Political Thought: Illiberal Conservatism for Modernization." Journal of Contemporary Politics 5(1), 181-215.

Kang, Won-Taek. 2005. "Generation, Ideology and Transformation of South Korean Politics." Korean Party Studies Review 4, 193-217

Kim, Byung-Kook. 2011. "The Leviathan: Economic Bureaucracy Under Park."

In Byung-Kook Kim and Ezra F. Vogel eds., The Park Chung Hee Era:

The Transformation of South Korea. Cambridge: Harvard University Press, 200-232.

Kim, Byung-Kook and Ezra F. Vogel, 2011. The Park Chung Hee Era: The Transformation of South Korea. Cambridge: Harvard University Press.

Kim, Dong-Choon. 2011. "War-Politics in Korea Under the Cold War and Anticommunist Order: State Violence and Limit of the Rule of Law." Economy and Society 89, 333-366.

Kim, Han-Jong. 2009. "The Educational Policy and the Publication of Textbooks by the Chosun Government-General." Studies on History Education 9, 295-329.

Kim, Hyunchul. 2004. "President Jung-Hee Park's Diplomacy and Initiatives for Peace-Building on the Korean Peninsula and the South-North Korea Relations in the Early 1970s." Unification Policy Studies 13, 81-99. 
Kim, Il-Young. 1995. "The Analysis and Evaluation of Politico-Economic Development Under Park Regime.” Korean Political Science Review 29(2), 181-215.

Kim, K. W. 1965. "Ideology and Political Development in South Korea." Pacific Affairs 38, 164-176.

Koschmann, J. Victor. 1987. The Mito Ideology: Discourse, Reform, and Insurrection in Late Tokugawa Japan, 1790-1864. Berkeley: University of California Press.

Kwon, Hyuk-Bom. 2000. "Anti-Communism Circuit in My Body and Authority.” In Jihyun Lim ed., Fascism Inside Us. Seoul: Samin, 49-63.

Kim, Seog Gun. 2012. "Successful Coup d'état, Revolution From Above, and 5.16: the Idea of Fatherland Modernization and Its Implication." Review of Korean and Asian Political Thoughts 11(1), 211-230.

Lee, Jeong-yong. 2008. "Factional Conflict of the Japanese Imperial Army in the 1930's." Journal of Korean-Japanese Military and Culture 6, 257280.

Lee, Kihun. 2002. "Teacher Training in the Colonial Period: Centering Around Daegu Normal School." Critical Studies on Modern Korean History 9, 41-76.

Lee, Wan-Bom. 2005. "Long-term Economic Development Plan of Park Chung Hee and the United States." In Sunghwa Jung ed., Issues and Subjects in Researches on Park Chung Hee Era. Seoul: Sunin, 155-255.

Lim, Jongguk. 1991. Silrok Chinilpa (Authentic Records of the ProJapanese Group during the Colonial Period), Institute for Research in Collaborationist Activities. Seoul: Dolbaegae.

Maruyama, Masao. 1963. Thought and Behaviour in Modern Japanese Politics. London: Oxford University Press.

Ma, Sang-Yoon. 2002. "Modernization Ideology and US Policy Towards South Korea: The Kennedy Administration and the 5.16 Coup d'état." Korean Journal of International Studies 42(3), 225-247. . 2003. "Security, Democracy and Park Chung Hee's Road: The Origins of the Yushin System Revisited." Korean Journal of International Studies 43(4), 171-196.

Matsumoto, Kenichi. 2010. Hyoden Kita Ikki [Korean language edition]. Seoul: Gyoyangin.

Milkis, Sidney M. and Jerome M. Mileur. 1999. Progressivism and the New Democracy. Amherst, MA: University of Massachusetts Press.

Mussolini, Benito. 1935. Fascism: Doctrine and Institutions. Rome: Ardita Publishers. 
Neocleous, Mark. 1997. Fascism. Minneapolis: University of Minnesota Press. Nugent, Walter. 2010. Progressivism - A Very Short Introduction. Oxford: Oxford University Press.

Park, Chung-Hee. 2005. Addresses to the Korean Nation - Collection of Park Chung Hee's Writings. Seoul: Dongsuhmunwhasa.

Park, Minyoung. 2004. "A Study of the Repatriation of Koreans in the Manchurian Army." Journal of Korean Independence Movement Studies 22, 137-163.

Park, Myung-lim. 2006. "Modern History of Korea, Park Chung Hee, and His Era: Ruling Ideology and Philosophy, State Strategy, and Democracy.” In Sunghwa Jung ed., Park Chung-Hee Era and Modern History of Korea. Seoul: Sunin.

Rhyu, Sang-young. 1996. "Between World System and State: Park ChungHee's Choice of Industrialization Strategy.” Korean Political Science Review 30(1), 151-179.

Sheng, Michael M. 1997. Battling Western Imperialism. Princeton, NJ: Princeton University Press.

Shin, Byung-Sik. 2006. "The Military Conscription System and the Myth of Sacred Obligation of National Defense During the Park Regime.” Economy and Society 72, 148-172.

Shin, Chi-Ho. 2008. "The State and Labor Relations Under the Park Chung Hee Regime." Korean Labor 16, 81-120.

Sin, Jubaek. 2002. "Korean Officers in the Manchu Government Army and the Korean Army." Critical Studies on Modern Korean History 9, 77-132.

Sohn, Bong-Scuk. 1983. "Political Culture and Anti-Communist Ideology in Korea.” Korean Political Science Review 17, 81-94.

Steiner, Phillippe. 2003. "Physiocracy and French Pre-Classical Political Economy.” In Warren J. Samuels, Jeff E. Biddle, and Jon B. Davis eds., A Companion to the History of Economic Thought. Malden: Blackwell Publishing.

Szpilman, Christopher W. A. 2002. "Kita Ikki and the Politics of Coercion." Modern Asian Studies 36(2), 467-490.

Tikhonov, Vladimir. 200o. "Korean Militarism that Destroys Humanity." In Jihyun Lim ed., Fascism Inside Us. Seoul: Samin.

Tobe, Ryoichi. 2003. Modern Japanese Army [Korean language edition]. Seoul: Korean Military Academy Hwarangdae Research Institute.

Westad, Odd Arne. 2003. Decisive Encounters - The Chinese Civil War, 19451950. Stanford: Stanford University Press.

Wilson, George M. 1966. “Kita Ikki’s Theory of Revolution.” Journal of Asian 
Studies 26(1), 89-99.

Yanga, Chitosi. 1940. "Recent Trends in Japanese Political Thought." Pacific Affairs 13, 125-137.

Yi, Pyŏng-chŏn. 2006. Developmental Dictatorship and the Park Chung-Hee Era: The Shaping of Modernity in the Republic of Korea. Paramus: Homa \& Sekey Books.

[Received Sep 27, 2017; Revised Nov 27, 2017; Accepted Jan 9, 2018] 